\title{
A PRELIMINARY ASSESSMENT FOR GROUNDWATER IN A PART OF NORTH CENTRAL NIGERIA USING LANDSAT ETM ${ }^{+}$
}

A. Y. B. ANIFOWOSE AND 0. O. ALADEJANA

(Received 29 June 2015; Revision Accepted 17 September 2015)

\section{ABSTRACT}

In a basement environment where groundwater is restricted to secondary permeability, structural analysis using remote sensing is a reliable and cheap method for the start-up process for groundwater exploration. In this study, remote sensing and GIS technology were employed as a major tool for groundwater prospecting in a part of North Central Nigeria; an area prone to water scarcity for more than half of every year.

The geological map of the study area, Landsat7 ETM+, and Shuttle Radar Topographic Mission (SRTM) imageries covering the area were employed in this study. Edge enhancements and directional filtering were carried out to enhance the visibility of lineaments on the Landsat imagery. To eliminate bias and subjectivity, Normalized Difference Vegetation Index (NDVI) and Digital Elevation Model (DEM) of the study area were processed for further lineament detection.

Results indicate that lineaments extracted from the Landsat imagery were in agreement with those obtained from the DEM. Those obtained from the NDVI analysis were also in agreement, except for a number of entirely new lineaments detected. This showed the importance of healthy vegetation aligned in a linear or curvilinear way as a major guide to detecting subsurface water-bearing zones that are not visible on the surface. Results also show that the dominant lineaments trend along the NE-SW direction. The northwest and central parts of the study area have relatively high lineament density, while the southern part has very low lineament density. These areas with high lineament density values are more feasible zones for groundwater prospecting.

KEYWORDS: Basement complex, Edge enhancement, Groundwater exploration, Landsat ETM ${ }^{+}$, NDVI

\section{INTRODUCTION}

The application of remote sensing technology in geology has greatly advanced through the years, with its usefulness spanning through mineral exploration, geological mapping, hydrogeological mapping, and structural geology, among others. Faults, joints, bedding planes and foliations are discontinuous structural trends that can be detected in various forms for several environmental applications which include landslide studies, hydrogeology and mineral exploration without being limited to using ground mapping techniques. Such discontinuous structural trends can be detected not only by carrying out ground mapping but also using remotely sensed data such as conventional aerial photographs and satellite imagery. Remote sensing products ranging from aerial photographs and different forms of satellite imageries have proved to be efficient in structural geology; the structures obtained from the field very much correlate with those obtained from satellite imagery, most of the time with perfect structural manifestations (Morelli and Piana 2006; Kaliraj et al. 2014). The synoptic view provided by remotely sensed data is a convenient way of understanding the interrelationship between various meso-and megastructures on the earth surface. Therefore, such features and their trends consequent on the deformational episodes experienced by rocks in the study area are clearly represented on satellite imageries.
Historically, lineament identification and extraction was performed using aerial photographs, stereopairs, and transparencies on light tables (Gupta 2003). With the launching of several satellite and sensor types, coupled with powerful computer algorithms for extraction and analysis, lineament identification has become much more precise and faster. Satellite imagery with hyper-fine spatial resolution has not been widely employed in lineament studies primarily due to cost and limited spectral resolution (Sander 2007, Machiwal et al. 2014; Nampak et al. 2014). However, lineament studies have been conducted using medium-resolution sensors (Drury and Andrews 2002, Lee and Moon 2002, Ricchetti 2002, Inzana et al. 2003, Hung et al. 2005, Arellano-Baezo et al. 2006, Khan and Glenn 2006, Meijerink et al. 2007, Sander 2007). The Landsat and ASTER series have proven to have a major advantage amongst other satellite imageries as being able to detect structural geology information as a result of their spectral resolutions in both visible and infra-red portion of the electromagnetic spectrum (Drury and AndrewsDeller, 2002). This fact is well illustrated in the research of Khan and Glenn (2006) where the application of ASTER data led to the discovery of two active strike-slip faults that were previously unmapped. Also, combinations of two or more sensors have been employed in lineament studies (Hung et al. 2005, Murphy and Burgess 2005, Akman and Tüfeçki 2004). Hung et al. (2005) compared lineament interpretations

A. Y. B. Anifowose, Department of Remote Sensing \& GIS, Federal University of Technology, P.M.B. 704, Akure, Nigeria.

O. O. Aladejana, Department of Remote Sensing \& GIS, Federal University of Technology, P.M.B. 704, Akure, Nigeria. 
from Landsat7 ETM ET $^{+}$and ASTER imagery and observed fewer erroneous results from ASTER derived lineaments compared with Landsat7 ETM+ derived lineaments. The difference was attributed to the higher spatial resolution of ASTER data.

The Basement complex in Nigeria covers about half of the country's landmass. Therefore it is important to understand the morpho-structural disposition of the geological terrain in order to proffer solution to groundwater problems associated with hard rock terrains. In north central Nigeria, the Basement complex forms an almost circular body extending from Kano, Bauchi, Lafia, Abuja, Minna, and Gusau and sharing boundaries with the Sokoto Basin, Chad/Gongola subbasin, and Benue Trough in the west, east and south respectively, as shown in Figure 1.

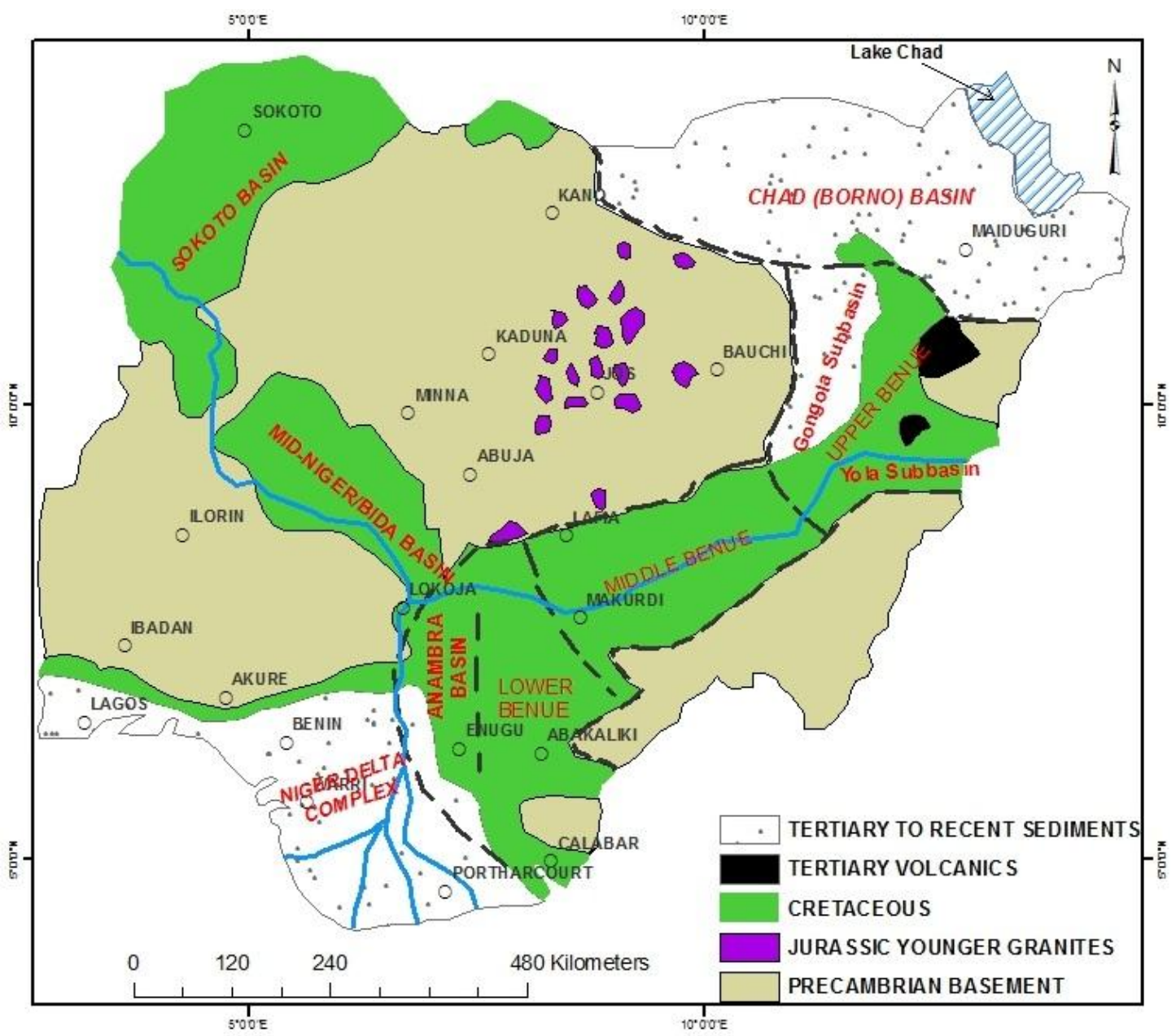

Figure 1: Generalized geologic map of Nigeria (Obaje, 2009)

\section{GEOLOGY OF THE STUDY AREA}

The study area spans over about $22,000 \mathrm{~km}^{2}$, between Latitudes $09^{\circ} 29^{\prime} 8.92^{\prime \prime} \mathrm{N}$ to $10^{\circ} 48^{\prime} 19.081^{\prime \prime} \mathrm{N}$, and
Longitudes $06^{\circ} 23^{\prime} 36.865^{\prime \prime} E$ to $07^{\circ} 46^{\prime} 36.354^{\prime \prime} E$. Major towns include Minna, Fuka, Gwagwada, Sarkin Pawa, Buruku, Sabon Birnin, Alawa, Sumaila, and Kugu as shown in Figure 


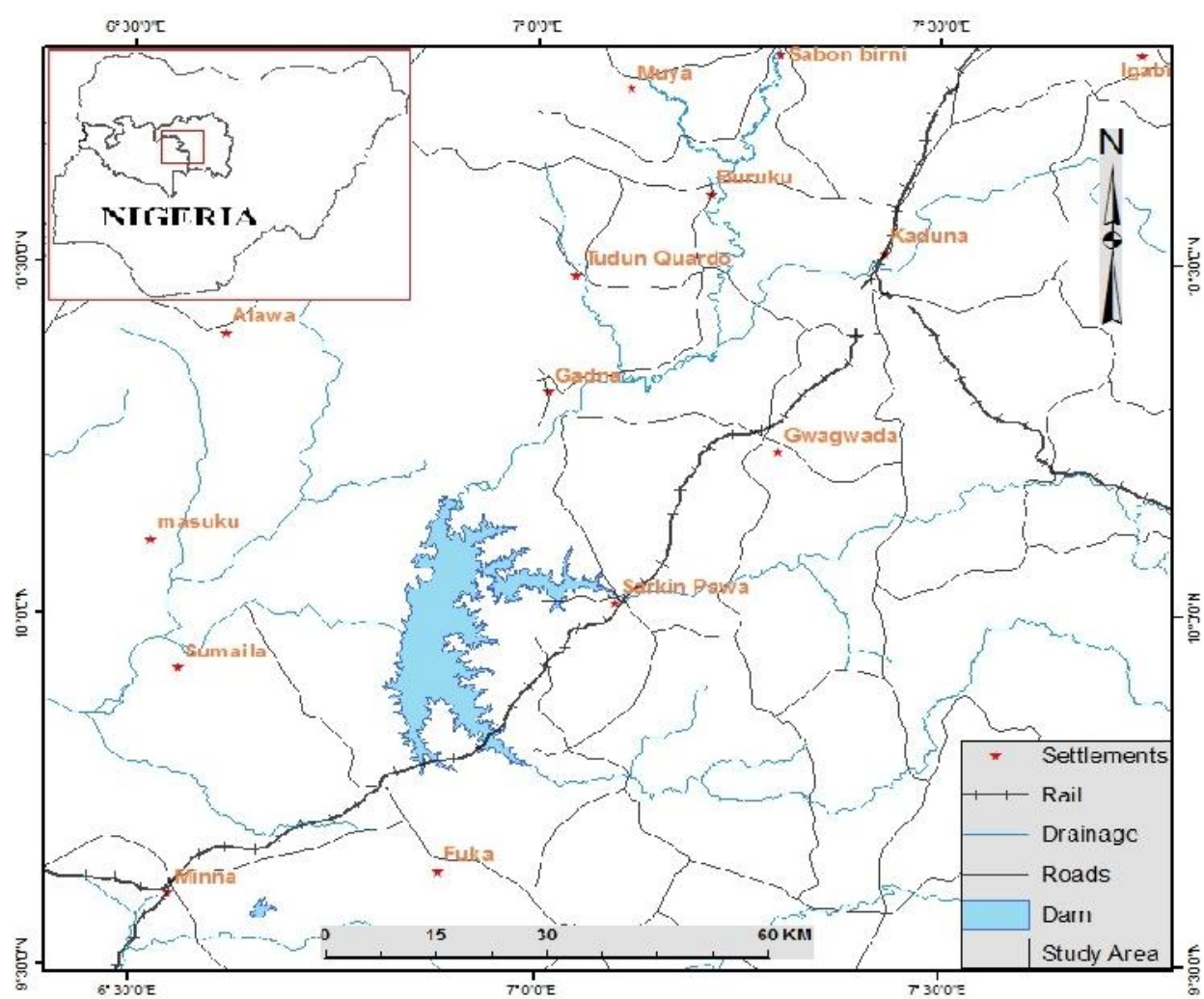

Figure 2: Location map of the study area

The underlying lithology consists of migmatites, gneisses, schists and other metasedimentary rocks, and granitoids (Oyawoye, 1972; Rahaman, 1988; Dada, 1989) as shown in Figure 3.

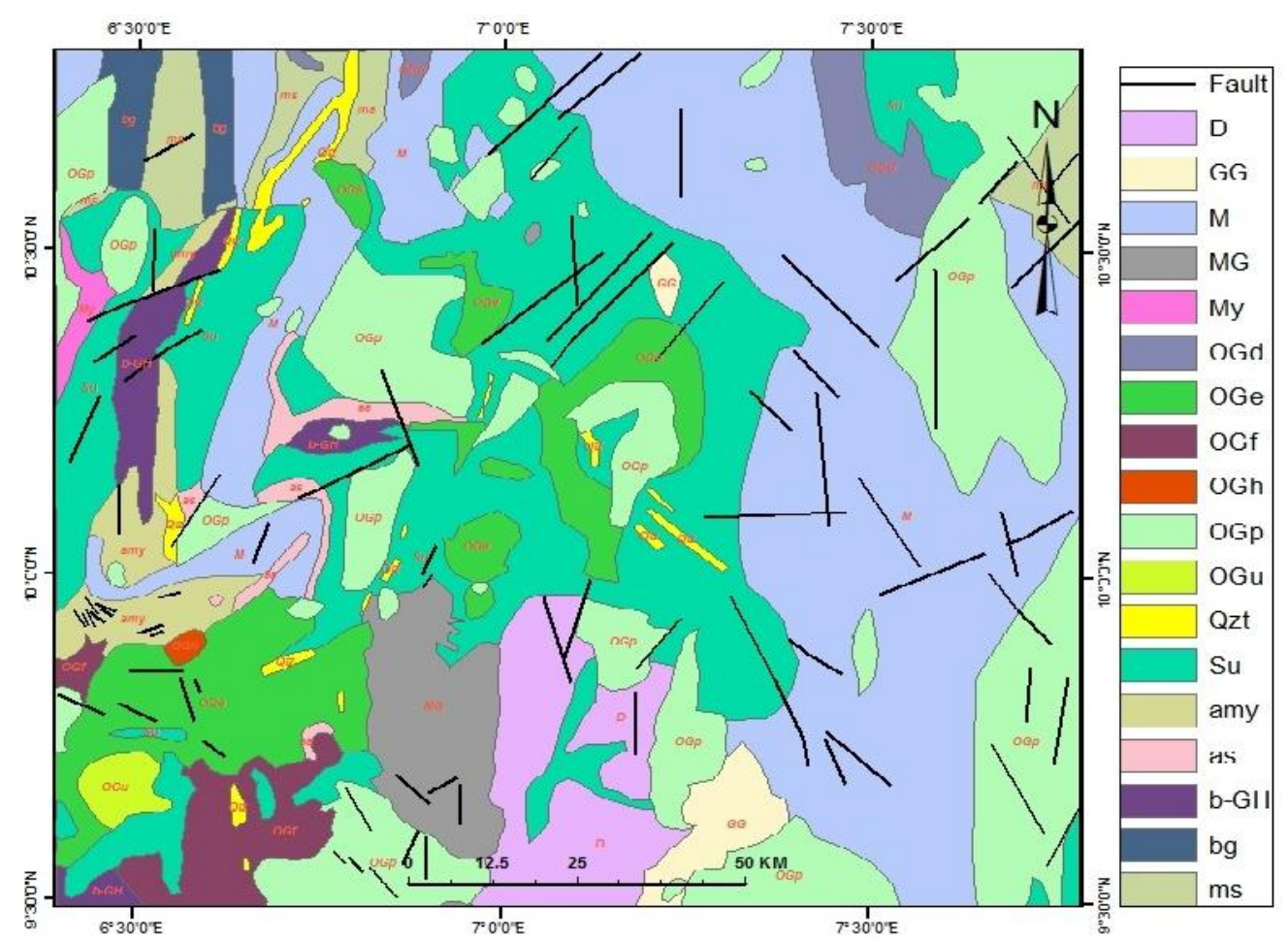

Figure 3: Geological map of the study area

Key: D-Dolerite, GG-Granite gneiss, M-Migmatite, MG-Migmatite gneiss, My-Mylonites, OGd-Biotite \& biotite hornblende granite, OGe-Medium to coarse grained biotic granite, OGf-Fine grained leucocratic granites, OGhCoarse porphyritic hornblende granite, OGp-Coarse grained porphyritic biotite\&biotite hornblende granite, OGuUndifferentiated granite, migmatite and granite, migmatite, porphyroblastic, Qzt-Quartzites, silicified shear zone, quartz vein, Su-Undifferentiated schist, including gneiss, fine grained flaggy quartzites, amy-myanites with intercalated amphibolites, as-amphibolite, $\mathbf{b}$-GH-Biotite hornblende gneiss, ms-Pelitic schist 
According to Rahaman (1988), the most dominant rock body in the study area is the Older Granites which are the most obvious manifestations of the Pan African orogeny, and attempts to classify with respect to timing during an orogenic event are valid over only short distances. They are believed to be pre-, synand post-tectonic rocks which cut both the migmatitegneiss-quartzite complex and the schist belts. They widely range in age (750-450 Ma) and composition, from tonalites and diorites through granodiorites to true granites and syenites, which represent a varied and long-lasting magmatic cycle associated with the Pan African orogeny (Obaje, 2009).

The schist belt in the study area bounds a migmatite- and gneisses-formed zone in the east, about $50 \mathrm{~km}$ wide (McCurry, 1976). This belt consists mainly of muscovite-biotite schists and phyllites interbedded with thin quartzites. The pelitic rocks include minor graphitic and feldspathic schists, and also contain frequent quartz and quartz-tourmaline veins. Interbedded quartzites are generally thin, but may be grouped to give sections which are dominantly quartzite. Units of well-bedded quartzites, several tens of metres thick, also occur. Minor rocks are spessartite quartzite, calc-silicate rocks and anthophyllite-cordierite schist. Amphibolites form occasional discontinuous bands, but the largest occurrence is only approximately $12 \mathrm{~m}$ thick (Obaje, 2009). The Kushaka schist belongs to the Kusheriki Schist Group, and it forms a number of curvilinear schist belts, separated by domes and anticlines of gneisses. The main rock type is semi-pelitic biotite-muscovite schist, in places containing garnet and staurolite
(Ajibade, 1982). Other rocks are phyllites, metasiltstones and graphitic schists. Several thick units of banded garnet grunerite iron formation are also found to be interbedded with the schists.

In the study area, paucity of insitu data on groundwater is a major challenge and this has resulted in poor knowledge of the hydro-physical characteristics of basement aquifers (Olorunfemi et al., 1999). This is the major cause of numerous failed/abortive hand dug wells and boreholes in the area, resulting in water scarcity. In view of these problems, the study focuses on developing a methodology for groundwater exploration using remote sensing (Landsat ETM+) and GIS techniques. It attempts to compare the results of lineaments obtained from Landsat imageries with those obtained from DEM, and analysis of NDVI of the study area. The essence is to provide information that will point towards areas where untapped water resources may be located in future.

\section{MATERIALS AND METHODS}

The Landsat $\mathrm{ETM}^{+}$of Path 189 and Row 053, acquired in 2001 over the study area was obtained from Global Land Cover Facility (GLCF) website. The geologic map covering the study area was scanned, georeferenced and digitized to obtain lithologic information. A mosaic of four 90-m SRTM DEM was obtained from the United States Geological Survey (USGS). Data gaps in the SRTM DEM were filled to produce a complete DEM coverage shown in Figure 4.

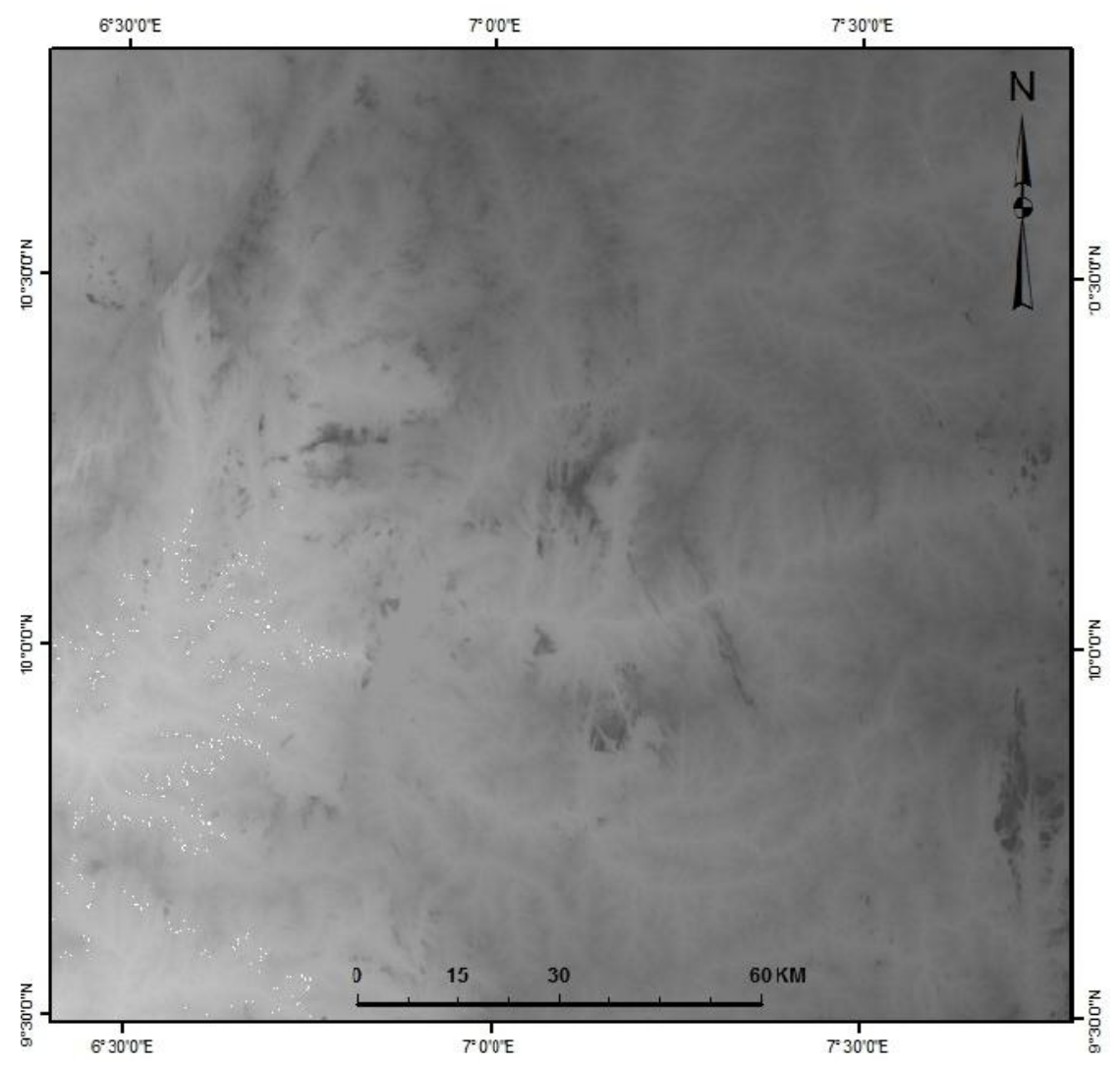

Figure 4: Digital Elevation Model of the study area 
All images were georeferenced to WGS 1984 and UTM Zone 32N.

The surface features making up a lineament in any particular area are usually caused by relief or contrast differences. The image used in this study is composed of 6 Visible and Near-Infrared (VNIR) and Shortwave Infrared (SWIR) bands with a $30 \mathrm{~m}$ resolution, and a panchromatic Band 8 with a $15 \mathrm{~m}$ resolution. The thermal band was not used for this analysis because of its low resolution, $120 \mathrm{~m}$. A sub scene covering the study area was created from the full scene Landsat-7 ETM+ image. It was subset to Latitudes $09^{\circ} 29^{\prime} 8.92^{\prime \prime} \mathrm{N}$ to $10^{\circ} 48^{\prime} 19.08^{\prime \prime} \mathrm{N}$, and Longitudes $06^{\circ} 23^{\prime} 36.87^{\prime \prime} \mathrm{E}$ to $07^{\circ} 46^{\prime} 36.35^{\prime \prime} \mathrm{E}$. In image preprocessing, the creation of band ratio images have proved to be very efficient in discriminating subtle differences in spectral variations especially in cases where individual scenes are masked by brightness variations. Because of the large variations in the spectral response as shown by Band 7, image histogram equalization was carried out with $10 \%$ stretching interval. The stretched image was then filtered in order to emphasize the linear features (e.g., edges) with high spatial frequency. Directional filters of $3 \times 3$ kernels were carried out in the North-South, East-West, and Northwest-Southeast directions using convolution method in order to enhance linear trends along those orientations. The resulting enhanced image revealed most of the lineaments which were hitherto digitized manually as shown in Figure 5b.

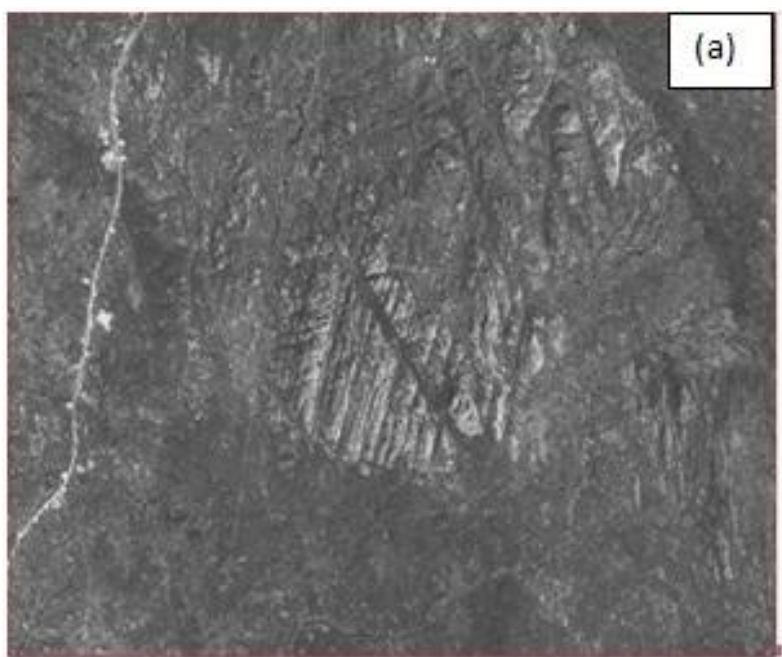

Fig. 5: Landsat: (a) after filtering

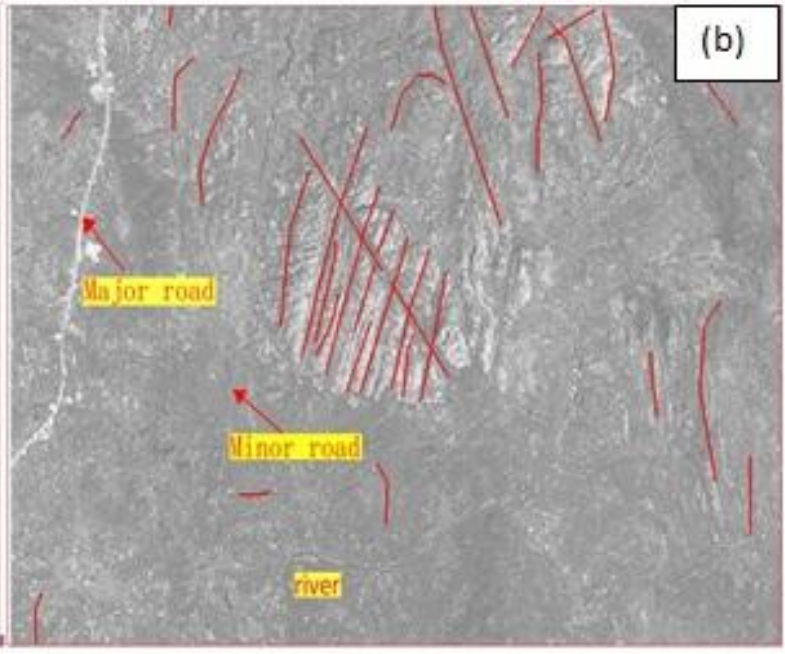

(b) showing extracted lineaments
To eliminate bias and subjectivity, the DEM and NDVI of the study area were processed for detection of lineaments. DEMs have shown to be useful for detecting lineaments because they can eliminate bias caused by inherent East-West sun illumination (Henderson et al., 1996; Yun and Moon, 2001). Studies that detect lineaments from DEMs alone rely on the assumption that majority of lineaments in a given area are geomorphic rather than tonal. This assumption is valid for most regions as valley and cliff orientations are typically controlled by faulting direction (Yun and Moon, 2001). The result of the mosaiced DEM was processed, and a hillshade surface with a vertical exaggeration of 2X was produced using ArcGISTM Surface Analysis
Tool. Lineaments occurring in hillshaded relief images are usually very much associated with variations occurring as sun illuminations. These are in turn related to changes in slope gradient. These changes reveal linear features. A $3 \times 3$ filter in the $x$-direction was applied to enhance the visibility of linear features occurring in the east and west as a result of changes occurring in that direction. It was also repeated in the $y$ direction for those occurring in the North and South. Inherent in this image were geomorphic lineaments, especially those occurring along fault-controlled cliffs. These lineaments were identified, and manually digitized as shown in Figure 6. 


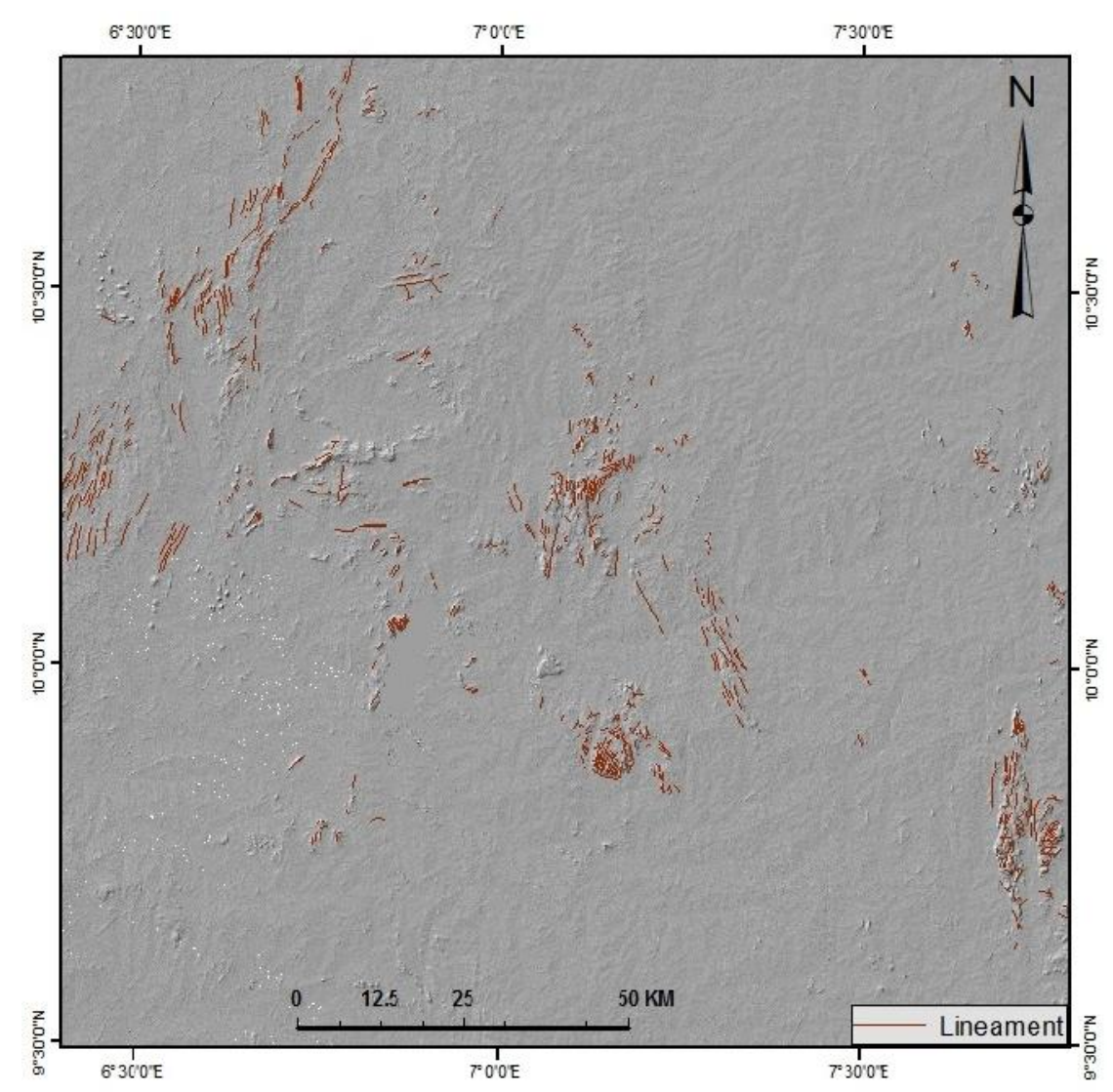

Figure 6: Lineament extraction from DEM

The NDVI which is based on the theory of a difference in reflectance in the near infrared (NIR) and red bands of the electromagnetic spectrum has its roots in this application. Its valid results fall between -1 and +1 with higher values indicating more green vegetation. Band 4 (NIR) and Band 3 (Red) were used for this procedure:
$N D V I=\frac{N I R-R E D}{N I R+R E D}$

This technique has its foundation on the fact that luscious vegetation in hard rock terrains usually aligns with water-bearing fractures (Mogaji et al., 2011). Those with denser and more active vegetations aligned in linear to curvilinear patterns were extracted appropriately by digitizing as shown in Figure 7 . 


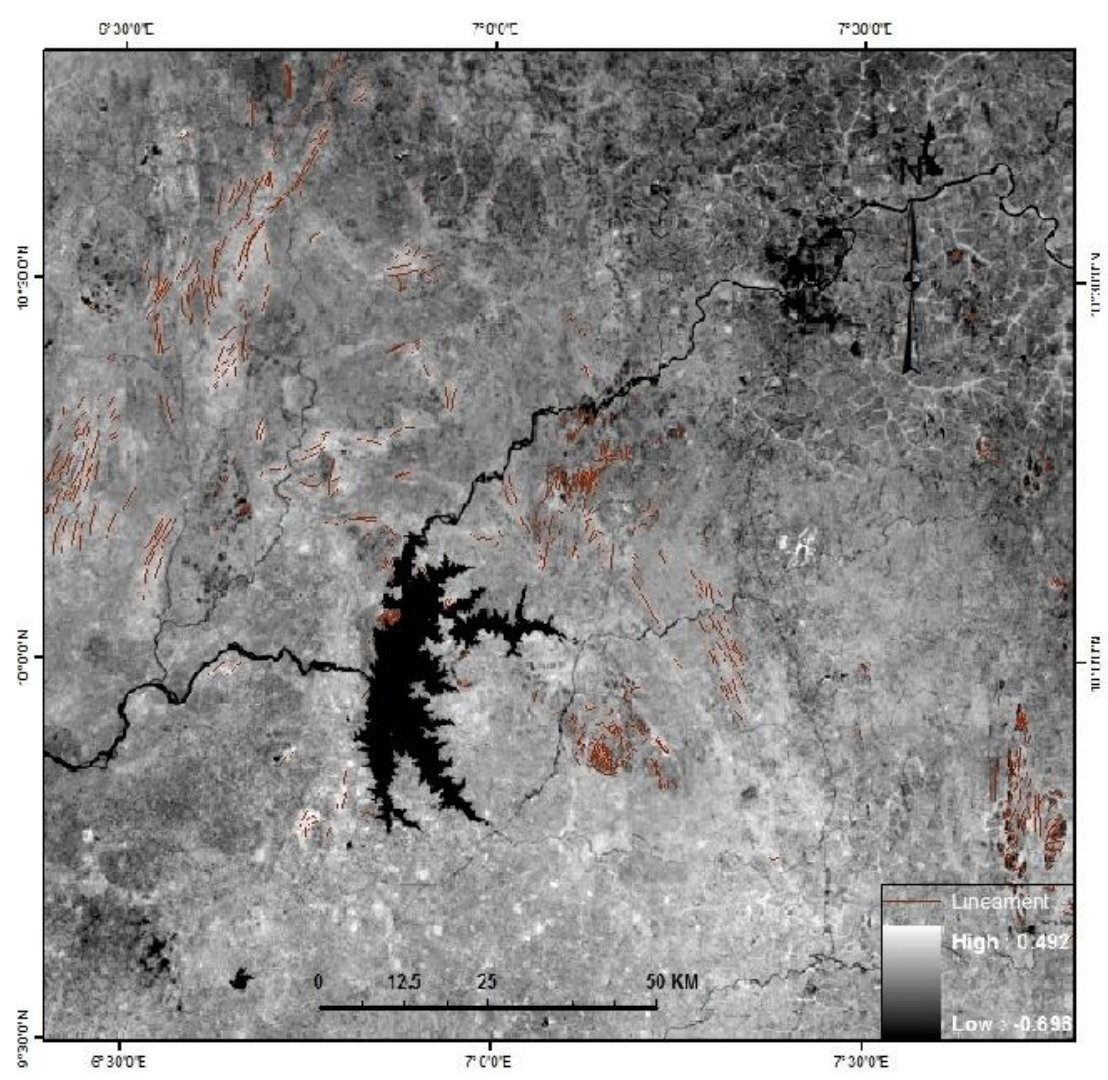

Figure 7: Lineament extraction from NDVI

\section{DISCUSSION OF RESULTS}

The lineaments obtained from the DEM analysis of the study area were the same obtained from the analysis of the Landsat imagery of the area. This further enunciates the fact that tonal changes and relief differences are major characteristics enhance the visibility of linear structural features in these imageries. Those obtained from the NDVI analysis were also the same with those previously obtained except in areas of thick vegetation covers where newer lineaments were obtained. The NDVI showed areas of healthy and flourishing vegetation. In this situation, this flourishing vegetation was aligned in both linear and curvilinear directions (Bruning, 2008). This showed the presence of shallow underground water sources in form of lineaments. The lineament map of the study area (Figure 8) depicts the structural trends obtained from the remote sensing analysis. 


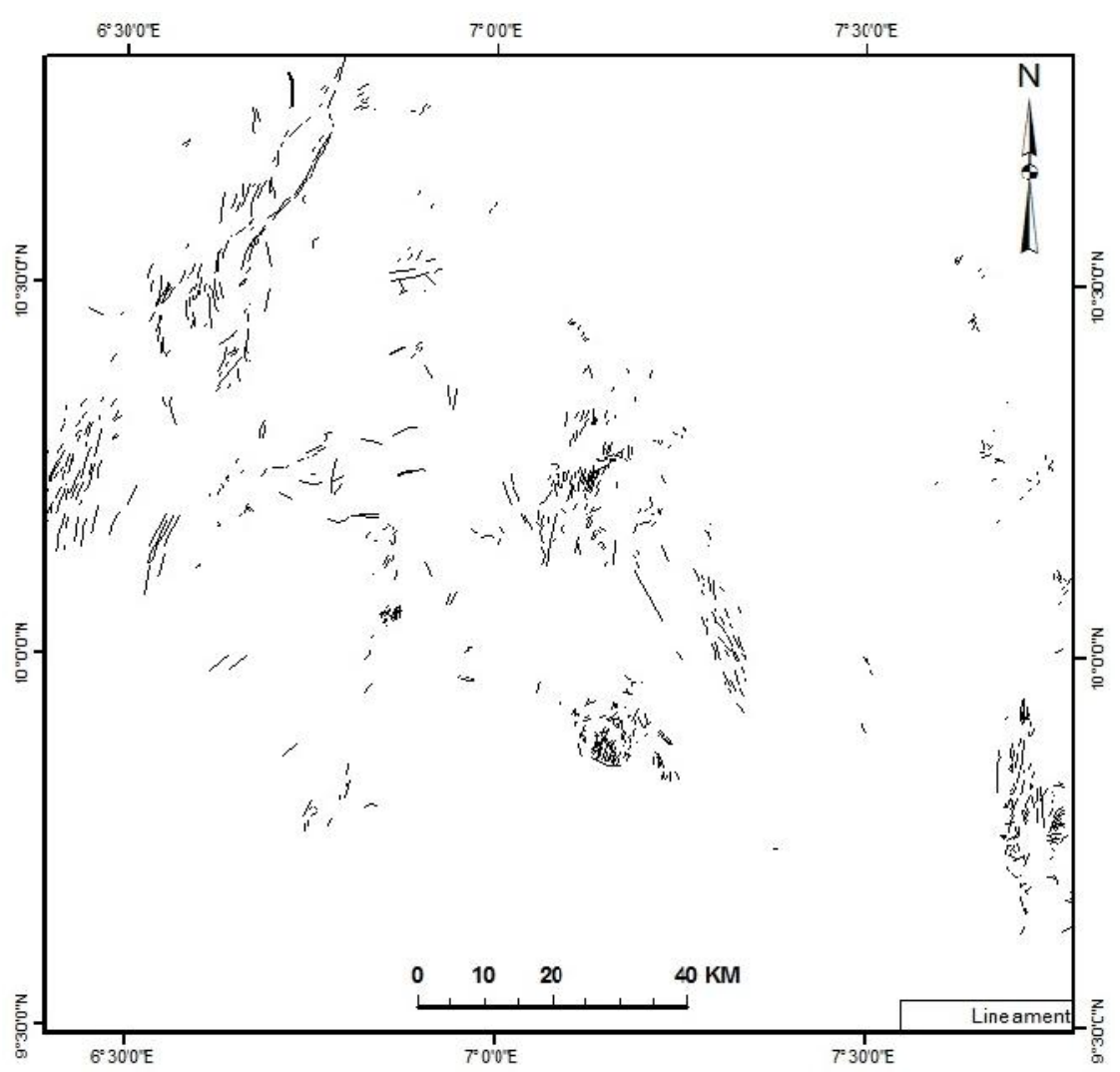

Figure 8: Lineament map of the study area

A total of 1570 lineaments were mapped; they indicate three distinct lineament directions as shown in the rose diagrams (Figure 9). A spatial analysis of the lineaments indicates lineament densities ranging between 1 and 12 per unit area.

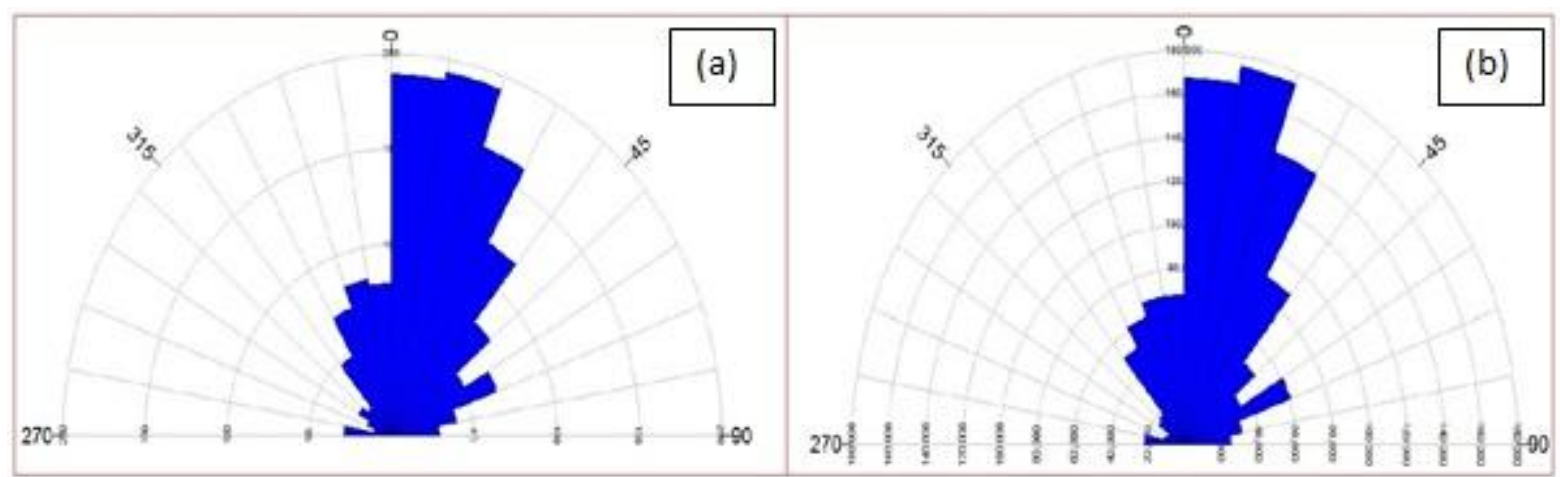

Figure 9: Lineament analyses: (a) Frequency-based (b) Length-based

Classification of the lineaments for their direction was done based on a $10^{\circ}$ interval. From the rose diagram obtained from the plotted lineaments, the dominant lineament direction was found to occur in the 0 - $10^{\circ}$ direction. A total of 192 lineaments occur in this interval, accounting for about $15 \%$ of the total mapped lineaments. The second dominant direction was $10^{\circ}-20^{\circ}$ with a total of 188 lineaments, and accounting for about $14 \%$ of the total lineaments. The third direction occurred in the $20^{\circ}-30^{\circ}$ orientation, a total of 155 lineaments accounting for about $12 \%$ of the total lineaments. The rose diagrams in Figure 9 show the frequency and length analyses of the extracted lineaments.

Fractures are zones of secondary porosity and permeability, which in turn have greater significance in groundwater potential and distribution in the hard rock terrains. In Alawa and Kugu areas, there exists high occurrence of lineament intersection points. These areas serve as promising areas for groundwater accumulation and could serve as sites for prolific water boreholes, and hand-dug wells of good yield. High lineament frequencies also found to occur in Kugu, Alawa, Gadna and Masuka. In these areas, the 
basement rocks outcrop or are close to the surface (i.e. areas with thin overburden) whereas in other parts of the study area, low lineament frequencies which are characteristic of areas with deeply buried basement rocks are observed (Edet et al., 1994). Therefore, regions with high lineament densities tend to favour high groundwater availability (Mogaji et al., 2011). The lineament density map (Figure 10) was generated and reclassified to obtain the values for the proximity of each area on the map to the extracted lineaments. According (Domingos et al., 2015) to Lineament density of an area can indirectly expose the groundwater potential, since the presence of lineaments usually denotes a permeable zone.

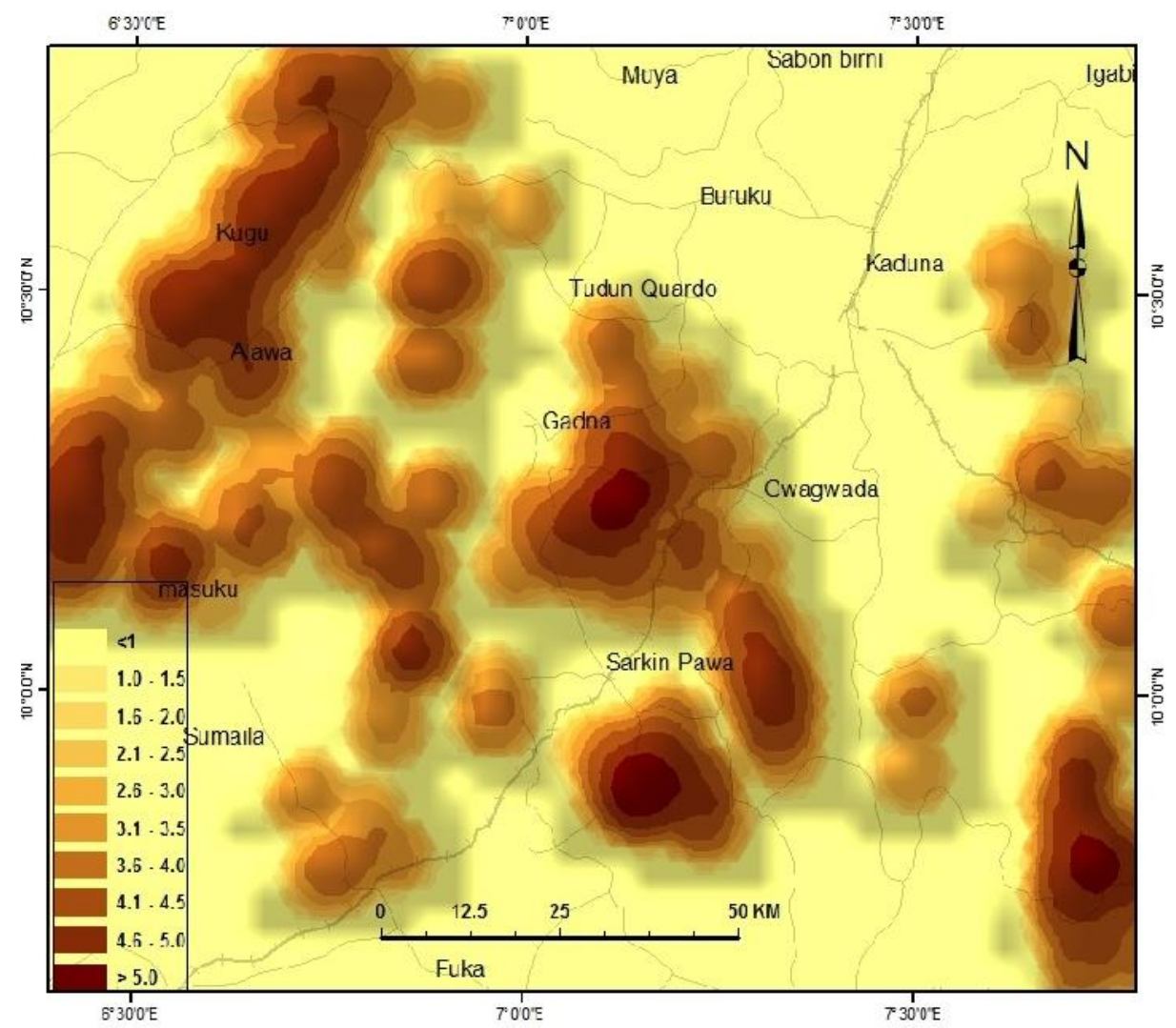

Figure 10: Lineament density map of the study area

An overlay of the lineaments obtained from the study on the geologic map of the study area showed that the lineaments occurred principally on the quartzites, coarse grained porphyritic biotite \& biotite hornblende granite, and the silicified shear zones. These rock types remarkable have very high secondary porosity and permeability

(Figure 


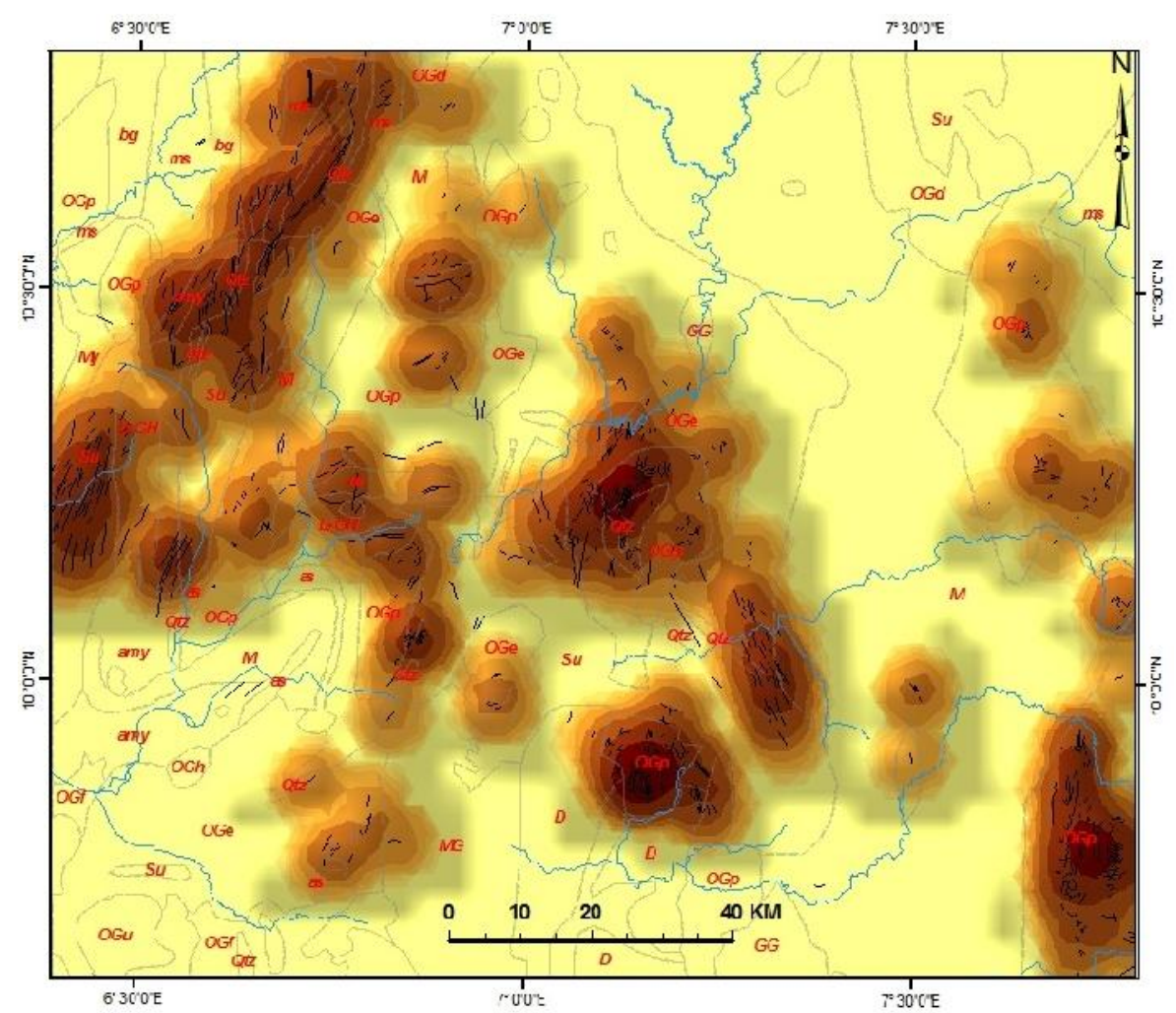

Figure 11: Lineament density map overlaid on the geology of the study area

Results indicate the existence of numerous long and short fractures with relatively high intersecting lineaments in the central, north-eastern and southwestern parts, but relatively low and evenly distributed in the other parts. Principally, the North western parts of the area, being zones of high lineament density are best for groundwater prospecting especially for community supply projects. This would be a good source of public water supply, producing an adequate amount of community water supply geared towards meeting the millennium development goal of adequate water supply. The eastern parts of the study area would be found to yield a remarkable amount of groundwater. It is suggested that these zones be quantitatively evaluated for the groundwater potential of the study area.

\section{CONCLUSIONS}

The result of the analysed lineaments shows that the lineaments/fractures within the study area are aligned mainly in the NNE-SSW directions, as obtained from the satellite imagery of the study area. This has demonstrated the efficiency of using remote sensing and GIS technology as a major start-up tool for groundwater exploration on a basement complex terrain.

As high lineament density areas have greater potential for groundwater prospecting, it is suggested that further geophysical investigation of the zones of high lineament density of the study area for its groundwater potential will prove to be very useful and efficient, providing a quantitative analysis of this resource.

This study can be described as a major tool required for proper water resources management towards sustainable development in Nigeria aimed at resolving food crisis in the region. In view of this it is suggested that other contributory factor to regional groundwater accumulation be considered to further increase the accuracy of this study. Most important of these is that the suggested zones of high groundwater accumulation should be combed with detailed geophysical investigation and mapping for proper quantitative evaluation of the volume of groundwater available in these zones.

\section{REFERENCES}

Ajibade, A. C., 1982. The cataclastic rocks of the Zungeru region and their tectonic significance. Jour. Min. Geol. 18, (2): 29-41.

Akman, A. Ü and Tüfekçi, K., 2004. Determination and characterisation of fault systems and geomorphological features by RS and GIS techniques in the WSW part of Turkey. Proceedings of XX ISPRS Congress: GeoImagery Bridging Continents, XXXV, Istanbul, 899-904.

Arellano-Baezo, A. A., Zverev, A. T and Malinnikov, V. A., 2006. Study of changes in the lineament structure, caused by earthquakes in South America by applying the lineament analysis to the ASTER (Terra) satellite data, Advances in Space Research, 37, (4): 690-697.

Bruning, J. N., 2008. A digital processing data compilation approach for using remotely sensed imagery to identify geological lineaments in hard-rock terrains: An application for groundwater exploration in Nicaragua. Michigan Technological University, 2008, 264. 
Dada, S. S., 1989. Geochemistry and Petrogenesis of the reworked Archean gneiss complex of North Central Nigeria: major and trace element studies on Kaduna amphibolites and migmatitic gneisses. Global J. Pure Appl. Sci., 5, 535-543.

Domingos, P., Sangam, S., Mukand, S. B and Sarawut, N., 2015. Delineation of groundwater potential zones in the Comoro watershed, Timor Leste using GIS, remote sensing and analytic hierarchy process (AHP) technique. Journal of Applied Water Science DOI 10.1007/s13201-015-0270-6. 134151.

Drury, S. A and Andrews-Deller, M. E., 2002. Remote sensing and locating new water sources. http://www.unoosa.org/pdf/sap/2002/ethiopia/pr esentations/12speaker01_1.pdf (accessed 22 May 2013).

Edet, A. E., Teme, S. C., Okereke, C. S and Esu, E. O., 1994. Lineament analysis for groundwater exploration in Precambrian Oban massif and Obudu Plateau, SE Nigeria. Journal of Mining and Geology, 30, (1): 87-95.

Gupta, R. P., 2003. Remote Sensing in Geology, 2nd Edition, (Berlin: Springer), 655.

Henderson, D. B., Ferrill, D. A and Clarke, K. C., 1996. Mapping geological faults using image processing techniques applied to hill-shaded digital elevation models. Proceedings of IEEE Symposium, 240-245.

Hung, L. Q., Batelaan, O and de Smedt, F., 2005. Lineament extraction and analysis, comparison of Landsat ETM and ASTER imageries, Case study: Suoimuoi tropical karst catchment, Vietnam. In: Proceedings of SPIE, 5983, 182193.

Inzana, J., Kusky, T., Higos, G and Tucker, R., 2003. Supervised classifications of Landsat TM band ratio images and Landsat TM band ratio image with radar for geological interpretations of central Madagascar, Journal of African Earth Sciences, 37, (1-2): 59-72.

Kaliraj, S., Chandrasekar, N and Magesh, N. S., 2014. Identification of potential groundwater recharge zones in Vaigai upper watershed, Tamil Nadu, using GIS-based analytical hierarchical process (AHP) technique. Arab J Geosci 7, (4): 13851401.

Khan, S. D and Glenn, N. F., 2006. New strike-slip faults and litho-units mapped in Chitral (N. Pakistan) using field and ASTER data yield regionally significant results. International Journal of Remote Sensing, 27, (18-20): 4495-4512.

Lee, T. $\mathrm{H}$ and Moon, W. M., 2002. Lineament extraction from Landsat TM, JERS-1 SAR, and DEM for geological applications, Institute of Electrical and Electronics Engineers IEEE, 3276-3278.

McCurry, P., 1976. The geology of the Precambrian to Lower Palaeozoic rocks of northern Nigeria - a review. In: Kogbe, C.A. (Ed.) Geology of Nigeria, Elizabethan Publishers, Lagos, 15-39.

Meijerink, A. M. J., Bannert, D., Batelaan, O., Lubczynski, M. W and Pointet, T., 2007. Remote Sensing Applications to Groundwater. In IHP-VI, Series on Groundwater No. 16, UNESCO, Paris, France, 304.

Machiwal, D., Rangi, N and Sharma, A., 2014. Integrated knowledge- and data-driven approaches for groundwater potential zoning using GIS and multi-criteria decision making techniques on hard-rock terrain of Ahar catchment, Rajasthan. Environ Earth Sci, India.

Nampak, H., Pradhan, B and Manap, M. A., 2014. Application of GIS based data driven evidential belief function model to predict groundwater potential zonation. J Hydrol 513:283-300.

Mogaji, K. A., Aboyeji, O. S and Omosuyi, G. O., 2011. Mapping of lineaments for groundwater targeting in the basement complex region of Ondo State, Nigeria, using Remote Sensing and GIS Techniques. International Journal of Water Resources and Environmental Engineering, 3, (7): 150-160.

Morelli, M and Piana, F., 2006. Comparison between remotely sensed lineaments and geological structures in intensively cultivated hills (Monferrato and Langhe domains, NW Italy). Int. J. Rem. Sens., 27, (20): 4471-4493.

Murphy, M. A and Burgess, W. P., 2005. Geometry, kinematics, and landscape characteristics of an active transtension zone, Karakoram fault system, Southwest, Tibet, Journal of Structural Geology, 28, (2): 268-283.

Obaje, N. G., 2009. Geology and mineral resources of Nigeria. Springer Dordrecht, Heidelberg, 221.

Olorunfemi, M. O., Ojo, J. S and Akintunde, O. M., 1999. Hydrogeophysical evaluation of the groundwater potential of Akure Area, Southwestern Nigeria. Journal of Mining and Geology. 35, (2): 207228.

Oyawoye, M. O., 1972. The Basement Complex of Nigeria. In: T.F.J. Dessauvagie and A.J. Whiteman (Eds.), African Geology, Ibadan, 66102.

Rahaman, M. A., 1988. Recent advances in the study of the basement complex of Nigeria. In: Oluyide PO, Mbonu WC, Ogezi AE, Egbuniwe IG, Umeji AC (Eds.) Precambrian Geology of Nigeria, Geological Survey of Nigeria, Kaduna, 11-43. 
Ricchetti, E., 2002. Structural geological study of Southern Apennine (Italy) using Landsat7 imagery, Institute of Electrical and Electronics Engineers (IEEE), 211-213.

Sander, P., 2007. Lineaments in groundwater exploration: a review of applications and limitations. Hydrogeology Journal, 15, 71-74.

Yun, S and Moon, W. M., 2001. Lineament extraction from DEM using drainage network. International Journal of Electrical and Electronic Engineering, 5, (10): 2337-2339. 